\title{
PENENTUAN LOKASI PERHENTIAN ANGKUTAN UMUM BERDASARKAN TEKNOLOGI SISTEM INFORMASI GEOGRAFIS \\ (Studi Kasus : Trayek K-14, pada Ruas Jalan Raya Setu, Kabupaten Bekasi)
}

\author{
Dr. I Made Suraharta, M.T. \\ Sekolah Tinggi Transportasi Darat \\ Jl. Raya Setu No. 89 Cibuntu Cibitung \\ Bekasi, Jawa Barat \\ e-mail info.p3m.sttd@gmail.com \\ Ir. Nico Djajasinga, M.Sc \\ Sekolah Tinggi Transportasi Darat \\ Jl. Raya Setu No. 89 Cibuntu Cibitung \\ Bekasi, Jawa Barat
}

\author{
Drs, Fauzi, M.T \\ Sekolah Tinggi Transportasi Darat \\ Jl. Raya Setu No. 89 Cibuntu Cibitung \\ Bekasi, Jawa Barat \\ Dra, Siti Umiyati, MM \\ Sekolah Tinggi Transportasi Darat \\ Jl. Raya Setu No. 89 Cibuntu Cibitung \\ Bekasi, Jawa Barat
}

\begin{abstract}
Determining the location of a public transport stop (shelter) is influenced by many factors. Criteria for determining the location shelter that is certain is that shelter planned trajectory should be on track to be served. In addition, the identification of the location of the passenger bag is an important factor that must be considered in determining shelter. Pockets of passengers will be adjacent to residential land use, land use thus becomes one of the important factors that may affect the decision-making shelter location. Other factors are: the location of the intersection, the travel distance, the plan stops should be close to the land use in the form of settlements by the buffer trajectory intersect with residential land use, site plans should stop as close as possible to the passenger bag. In addition the site plan public transport stop / stop prohibited from being at the intersection with a radius of less than 25 meters is also a criteria for determining the location shelter consideration.
\end{abstract}




\begin{abstract}
Abstrak
Penetapan lokasi tempat perhentian angkutan umum (TPAU) dipengaruhi oleh banyak faktor. Kriteria penentuan lokasi TPAU yang sudah pasti adalah bahwa TPAU yang direncanakan harus berada pada jalur trayek yang akan dilayaninya. Selain itu, identifikasi lokasi kantung penumpang menjadi faktor penting yang harus dipertimbangan dalam penetapan TPAU. Kantung-kantung penumpang akan berdekatan dengan tata guna lahan pemukiman, dengan demikian tata guna lahan menjadi salah satu faktor penting yang dapat mempengaruhi pengambilan keputusan lokasi TPAU. Faktor-faktor lainnya yaitu: lokasi simpang, jarak perjalanan, rencana halte harus berada dekat dengan tata guna lahan berupa pemukiman dengan melakukan intersect antara buffer trayek dengan tata guna lahan pemukiman, rencana lokasi halte harus sedekat mungkin dengan kantung penumpang. Selain itu rencana lokasi perhentian angkutan umum/halte dilarang berada di simpang dengan radius kurang dari 25 meter juga menjadi kriteria pertimbangan penetapan lokasi TPAU.
\end{abstract}

\title{
A. LATAR BELAKANG
}

Penentuan lokasi dan jumlah perhentian angkutan umum sangat penting untuk optimalisasi penggunaan perhentian angkutan umum, dengan kata lain fasilitas perhentian yang akan dibangun dapat dimanfaatkan semaksimal mungkin untuk proses pergantian moda angkutan, sedemikian hingga sehingga fasilitas yang telah diadakan tidak mubasir, atau tidak termafaatkan dikarenakan salah dalam penempatan lokasinya dan/atau tidak tersedia pada lokasi yang seharusnya. Pembangunan perhentian angkutan umum yang kurang tepat akan mengakibatkan bertambahnya permasalahan transportasi, sebab banyak masyarakat/calon penumpang angkutan umum yang seharusnya menjadi target pengguna menjadi malas untuk menggunakan fasilitas ini dikarenakan lokasi perhentian angkutan umum yang terlalu jauh. Selain itu perhentian angkutan umum yang didesain kurang tepat juga malah sering digunakan sebagai lahan parkir untuk kendaraan lain.

\section{B. PERUMUSAN MaSAlah}

Berkaitan dengan uraian permasalahan di atas, maka yang menjadi permasalahan dalam studi ini, adalah :

1. Dimanakah lokasi perhentian angkutan umum yang tepat ?

2. Berapakah jumlah perhentian angkutan umum yang diperlukan?

3. Jenis perhentian angkutan umum yang seperti apa yang tepat digunakan? 


\section{RUANG LINGKUP PENELITIAN}

Ruang permasalahan dan pembahasan dalam penelitian ini dibatasi antara lain sebagai berikut :

1. Penelitian ini hanya menentukan lokasi halte pada rute yang telah ditentukan yaitu angkutan pedesaan Kode Trayek K-14, yang melayani Kampung Utan-Serang (Setu) di Kabupaten Bekasi;

2. Penentuan lokasi perhentian angkutan umum dalam penelitian ini tidak membahas mengenai kompetisi dengan angkutan umum lainnya, dikarenakan hanya ada Trayek K-14 pada jalur jalan yang diteliti..

3. Titik acuan permintaan penumpang yang akan melakukan proses transfer/naik turun angkutan adalah titik lokasi dimana penumpang melakukan aktifitas naik dan turun angkutan umum yang teridentifikasi pada saat observasi lapangan.

4. Pada penelitian ini tidak mempertimbangkan faktor biaya pembangunan perhentian angkutan umum.

\section{MAKSUD DAN TUJUAN PENELITIAN}

Tujuan dari penelitian ini antara lain

1. menentukan lokasi perhentian angkutan umum sehingga dapat memberikan akses yang layak ke tempat perhentian terdekat kepada semua penumpang dengan jumlah perhentian yang minimum tetapi dapat memenuhi semua titik permintaan di sepanjang rute (coverage area),

2. menentukan jumlah perhentian angkutan umum Trayek K-14 (Kampung Utan - Serang (Setu)).

3. menentukan desain perhentian angkutan umum yang tepat sesuai dengan karakteristik guna lahan dan tipe serta dimensi ruas jalan.

\section{E. METODE PENDEKATAN}

Secara umum, penetapan lokasi tempat henti angkutan umum adalah dengan memperhatikan lokasi kantung-kantung penumpang. Selain itu, lokasi tempat henti didekatkan dengan sumber-sumber bangkitan dan tarikan penumpang. Sumber-sumber bangkitan dan tarikan penumpang adalah titik-titik lokasi kantung-kantung penumpang. Penentuan lokasi tempat henti dengan mempertimbangkan kantung-kantung penumpang, disaring dengan mempertimbangkan intensitas calon penumpang dan jarak antar lokasi kantung penumpang. 
Dalam hal sumber-sumber bangkitan dan tarikan perjalanan, yang selanjutnya menumbuhkan lokasi-lokasi kantung penumpang dapat diidentifikasi dengan memperhatikan pengunaan lahan dan kontur serta kondisi guna lahan. Hal ini dapat didekatkan dengan penggunaan alat bantu berupa peta rupa bumi yang dikombinasikan dengan sistem informasi geografis, yang dapat dihasilkan dari perangkat bantu berupa MapInfo, ArcGis, dan lain sebagainya.

Pendekatan pemecahan masalah penentuan lokasi perhentian angkutan umum pada Angkutan Kota K-14 trayek Kampung Utan-Setu-Serang dalam penelitian ini dilakukan dengan menerapkan teknologi informasi geografis yang dapat merepresentasikan peta rupa bumi, terutama pada wilayah kajian yaitu jalur rute Trayek K-14.

Adapun tahapan pengerjaan penetapan lokasi tempat henti angkutan umum dengan menerapkan teknologi informasi geografis adalah sebagai berikut:

Tahap pertama, mengamati dan mengumpulkan data yang dibutuhkan seperti data naik dan turun penumpang, tata guna lahan, lokasi kantung penumpang, jarak naik-turun penumpang terhadap lokasi persimpangan.

Tahap kedua, membuat diagram alir penentuan lokasi perhentian angkutan umum dengan penerapan teknologi informasi geografis dengan maksud untuk mempermudah dalam proses pengolahan data dan analisa.

Tahap ketiga, mensimulasikan data tata guna lahan, jarak persimpangan, dan jarak pelayanan dengan menggunakan perangkat lunak geografis dengan sistem skoring.

Tahap keempat, mengkombinasikan hasil analisa perangkat lunak dengan data hasil lapangan untuk dapat menghasilkan lokasi tempat henti angkutan umum yang optimal dengan menggunakan sistem skoring.

\section{F. PENETAPAN LOKASI TEMPAT HENTI ANGKUTAN UMUM DALAM JARINGAN PELAYANAN ANGKUTAN UMUM}

Sebagaimana telah disebutkan sebelumnya bahwa penetapan lokasi tempat perhentian angkutan umum (TPAU) dipengaruhi oleh banyak faktor. Kriteria penentuan lokasi TPAU yang sudah pasti adalah bahwa TPAU yang direncanakan harus berada pada jalur trayek yang akan dilayaninya. Selain itu, identifikasi lokasi kantung penumpang menjadi faktor penting yang harus dipertimbangan dalam penetapan TPAU. Dalam proses pengolahan data dan analisa dibantu 
dengan perangkat aplikasi sistem informasi geografis. Berikut adalah penjelasan penetapan lokasi berdasarkan kriteria-kriteria sebagaimana disebutkan diatas.

1. Jalur Trayek

Jalur trayek yang dimaksud adalah jalur trayek angkutan umum K-14 yang didapat dari data trayek yang divalidasi dengan melakukan pengecekan di lapangan, yang kemudian dilakukan ploting trayek pada peta. Hal ini dilakukan untuk memperjelas ruang lingkup pembahasan pada penelitian ini.

2. Lokasi Kantung Penumpang

Pada tahap ini telah dilakukan survey naik dan turun penumpang, dari hasil survey tersebut maka dapat diketahui titik-titik lokasi pada trayek angkutan K-14 yang yang memiliki jumlah penumpang. Setelah diketahui lokasi kantung penumpang, selanjutnya dilakukan penentuan lokasi kantung penumpang dipeta pada jalur trayek kajian. Sehingga untuk lokasi dengan kantung penumpang ditambahkan skor dengan nilai 5.

3. Tata Guna Lahan Pemukiman

Merupakan daerah pembangkit perjalanan yang relatif besar. Dalam hal ini dilakukan skoring atau pemberian nilai sesuai dengan perkiraan besarnya perjalanan yang dibangkitkan daerah tersebut. Pemberian skor tersebut seperti ditunjukkan pada tabel di bawah ini:

Tabel 1. Dibangkitkan oleh Guna Lahan Tertentu

\begin{tabular}{clc}
\hline No. & \multicolumn{1}{c}{ Jenis Tata Guna Lahan } & Skor \\
\hline 1 & Perumahan/Perkantoran & 5 \\
2 & Perdagangan/Pendidikan & 5 \\
3 & Kawasan perumahan kepadatan rendah (Pemukiman) & 3 \\
4 & Pertanian \& lahan terbuka, FASUM & 2 \\
5 & Industri & 4 \\
6 & Hutan & 1 \\
7 & Sungai, Kolam, \& lahan tergenang & 1 \\
\hline
\end{tabular}




\section{Lokasi Simpang}

Bedasarkan standar teknis penentuan halte, disebutkan bahwa penempatan halte adalah minimal 50m dari titik simpang sehingga tidak saat angkutan umum berhenti tidak akan mengganggu lalu lintas kendaraan lain yang berada di simpang tersebut. Untuk titik simpang ini kami tidak melakukan skoring dikarenakan hanya 1 parameter utama, sehingga tidak bisa dilakukan skoring.

5. Jarak Pelayanan

Sesuai dengan standar teknis penentuan halte, jarak berjalan kaki dari rumah ke tempat pemberhentian angkutan umum (halte) yang masih bisa diterima olah masyarakat adalah maksimal 500m. Oleh karena itu kami melakukan skoring terhadap jarak pelayanan atau jarak berjalan kaki masyarakat menuju ke tempat pemberhentian angkutan umum (halte). Penentuan jarak berjalan kaki dengan melakukan buffer dari jalur trayek dengan jarak tertentu. Pemberian skor berdasarkan jarak pelayanan tersebut adalah sebagai berikut:

Tabel 2. Skoring atau Pemberian Nilai Penentuan Jarak Berjalan kaki ke Lokasi Perhentian Angkutan Umum dengan Melakukan buffer dari Jalur Trayek dengan Jarak Tertentu

\begin{tabular}{lcc}
\hline NO & JARAK (METER) & PEMBOBOTAN \\
\hline 1 & 25 & 5 \\
2 & 50 & 4 \\
3 & 75 & 3 \\
4 & 100 & 2 \\
5 & 125 & 1 \\
\hline
\end{tabular}

6. Rencana Halte Harus Berada Dekat Dengan Tata Guna Lahan Berupa Pemukiman Dengan Melakukan Intersect Antara Buffer Trayek Dengan Tata Guna Lahan Pemukiman Rencana halte memiliki pembobotan nilai yang tinggi bila berada pada lokasi area antara tata guna lahan pemukiman dan perdagangan. Sehingga dengan teknik intersect antara buffer trayek dan TGL akan mempermudah dalam menentukan area terbaik yang akan digunakan sebagai rencana lokasi titik halte. Namun dikarenakan TGL tidak ada maka dilakukan secara manual.

7. Rencana Lokasi Halte Harus Sedekat Mungkin dengan Kantung Penumpang Hal terpenting bahwa penentuan lokasi halte ditentukan dari lokasi titik penumpang dari hasil survey lapangan. 
8. Rencana Lokasi Perhentian Angkutan Umum/Halte Dilarang Berada di Simpang dengan Radius kurang dari 25 Meter, Rencana lokasi halte yang baik adalah tidak berada tepat dengan persimpangan jalan, karena akan menjadi hambatan jalan. Dengan menjadi hambatan jalan akan mengganggu operasional persimpangan sehingga menambah waktu perjalanan. Rencana lokasi halte yang baik adalah tidak berada tepat dengan persimpangan jalan, karena akan menjadi hambatan jalan. Dengan menjadi hambatan jalan akan mengganggu operasional persimpangan sehingga menambah waktu perjalanan. Sehingga pada perencanaan lokasi halte yang berada di simpang perlu dilakukan relokasi titik rencana halte yang masuk dalam radius larangan lokasi halte di simpang dengan radius 25 meter.

9. Melakukan Penilaian Skala Prioritas Terhadap Rencana Lokasi TPAU

Penentuan prioritas ini dilakukan dengan cara menggabungkan 2 nilai parameter yaitu parameter karakteristik tata guna lahan dan jumlah permintaan perjalanan atau parameter kantung penumpang.

Penilaian dengan melakukan perbandingan antara kedua parameter, penilaian layak diberikan pada kandidat TPAU yang hanya mengacu dari karakteristik tata guna lahan dan juga jarak antar kandidat TPAU.

Tabel 3. Penilaian Skala Prioritas Terhadap Rencana Lokasi TPAU

\begin{tabular}{lcccc}
\hline \multicolumn{1}{r}{ Lokasi Rencana Halte } & Skor TGL & Skor Kantung PNP & Total Skor & Prioritas Pembangunan \\
\hline Kampung Utan Terminal & 5 & 5 & 10 & Sangat Layak \\
Kampung Utan Bpr & 5 & 5 & 10 & Sangat Layak \\
Kampung Utan Al Muslim & 5 & 0 & 5 & Layak \\
Simpang 3 Sate Solo & 5 & 5 & 10 & Sangat Layak \\
Simpang Kalimalang & 5 & 5 & 10 & Sangat Layak \\
Sdn Cibuntu 01 & 5 & 5 & 10 & Sangat Layak \\
Gazebo & 5 & 5 & 10 & Sangat Layak \\
Gang Onte & 3 & 5 & 8 & Layak \\
Sd Cibuntu 06 & 5 & 5 & 10 & Sangat Layak \\
Gor Sisilia & 2 & 0 & 2 & Tidak Layak \\
Atm Bni Sttd & 3 & 5 & 8 & Layak \\
Perum Bukopin & 5 & 5 & 10 & Sangat Layak \\
Sttd & 5 & 5 & 10 & Sangat Layak \\
Bpjlskb & 5 & 5 & 10 & Sangat Layak \\
Perumahan Hubdat & 5 & 5 & 10 & Sangat Layak \\
\hline
\end{tabular}




\begin{tabular}{lcccc}
\hline \multicolumn{1}{c}{ Lokasi Rencana Halte } & Skor TGL & Skor Kantung PNP & Total Skor & Prioritas Pembangunan \\
\hline Simpang 3 Rawa Banteng & 5 & 5 & 10 & Sangat Layak \\
Industri Batik & 4 & 0 & 4 & Tidak Layak \\
Komplek Gedung Pertanian & 5 & 0 & 5 & Layak \\
Perum Grand Mutiara Gading & 5 & 5 & 10 & Sangat Layak \\
& & & & Sangat Layak \\
Perum Graha Mustika Media & 5 & 5 & 10 & Sangat Layak \\
Perum Graha Asri & 5 & 5 & 10 & Sangat Layak \\
Sd Telajung 01 & 5 & 5 & 10 & Sangat Layak \\
Pasar Setu & 5 & 5 & 10 & Sangat Layak \\
Pertigaan Setu & 5 & 5 & & 10 \\
\hline
\end{tabular}

Dari skala prioritas pembangunan diatas tidak dapat langsung digunakan sebagai acuan pembangunan, akan tetapi perlu memperhitungkan jarak antara rencana lokasi titik tempat perhentian angkutan umum, sehingga jarak rencana lokasi TPAU tidak boleh terlalu pendek atau jauh. Dimana secara konsensus diketahui bahwa jarak antar TPAU paling jauh adalah 400 meter.

Dari hasil analisa jarak antar potensi lokasi perhentian angkutan umum diatas maka dapat diketahui bahwa potensi lokasi perhentian angkutan umum yang dapat dipilih untuk menjadi rencana lokasi TPAU. Berdasarkan hasil pemilihan, terdapat 17 lokasi TPAU yang representatif untuk dapat dibangun guna meningkatkan pelayanan jalur angkutan Trayek K14 dan sebagai justifikasi prioritas pembangunan TPAU.

Tabel 4. Justifikasi Lokasi Perhentian Angkutan Umum Terpilih untuk Trayek K-14 di Kabupaten Bekasi 


\begin{tabular}{|c|c|c|c|}
\hline No. & $\begin{array}{l}\text { Lokasi Tempat Perhentian } \\
\text { Angkutan Umum }\end{array}$ & Prioritas Pembangunan & Dipenuhi Oleh Kandidat Halte \\
\hline 1 & Kampung Utan (Terminal) & Sangat Layak & Kampung Utan (Terminal) \\
\hline 2 & Simpang 3 Sate Solo & Sangat Layak & Simpang 3 Sate Solo \\
\hline 3 & SDN Cibuntu 01 & Sangat Layak & SDN Cibuntu 01 \\
\hline 4 & Gazebo & Sangat Layak & Gazebo \\
\hline 5 & Gang Onte & Layak & Gang Onte \\
\hline 6 & SDN Cibuntu 06 & Sangat Layak & SDN Cibuntu 06 \\
\hline 7 & ATM BNI STTD & Layak & ATM BNI STTD \\
\hline 8 & STTD & Sangat Layak & STTD \\
\hline 9 & BPLJSKB & Sangat Layak & BPLJSKB \\
\hline 10 & Perumahan Hubdat & Sangat Layak & Perumahan Hubdat \\
\hline 11 & Simpang 3 Rawa Banteng & Sangat Layak & Simpang 3 Rawa Banteng \\
\hline 12 & Industri Batik & Tidak Layak & Industri Batik \\
\hline 13 & Komplek Gedung Pertanian & Layak & Komplek Gedung Pertanian \\
\hline 14 & Perum Grand Mutiara Gading & Sangat Layak & Perum Grand Mutiara Gading \\
\hline 15 & Perum Graha Asri & Sangat Layak & Perum Graha Asri \\
\hline 16 & SD Telajung 01 & Sangat Layak & SD Telajung 01 \\
\hline 17 & Pertigaan Setu (Terminal) & Sangat Layak & Pertigaan Setu \\
\hline
\end{tabular}

Dari data rencana lokasi TPAU diatas masih perlu dilakukan pengamatan daerah titik lokasi saat pembangunan TPAU, perlu ditentukan titik lokasi yang benar-benar tepat, dengan maksud terdapat lahan kosong atau lokasi tertentu yang memungkinkan dibangunnya TPAU. Hal ini berkaitan dengan tipe tempat perhentian angkutan umum yang akan dibangun.

\section{G. PENETAPAN TIPE TEMPAT PERHENTIAN ANGKUTAN UMUM (TPAU) DALAM JARINGAN PELAYANAN ANGKUTAN UMUM K-14.}


Sebagaimana telah dijelaskan pada bagian sebelumnya, dijelaskan bahwa terdapat 10 (sepuluh) tipe tempat perhentian angkutan umum yang dipengaruhi oleh ketersediaan lahan, tingkat kebutuhan terhadap lindungan (atap atau rumah-rumah), ada tidaknya fasilitas pejalan kaki berupa trotoar dan apakah lebar jalur lalu lintas per arah lebih dari 5,75 meter. Tipe-tipe tempat perhentian angkutan umum tersebut dapat ditetapkan secara empiris berdasarkan bagan alir penetapan tipe tempat perhentian angkutan umum dengan menjawab (ya atau tidak) atas 4 (empat) pertanyaan sebagai berikut:

- apakah mungkin dibuat teluk bus?

- Apakah perlu lindungan (halte)?

- Apakah ada trotoar?

- Apakah jalur lalu lintas per arah > (lebih besar dari) 5,75?

Ke empat pertanyaan diatas sekaligus sebagai kriteria pemilihan tipe tempat perhentian angkutan umum (TPAU). Rekomendasi Tipe Tempat Perhentian Angkutan Umum (TPAU) di sepanjang jalur pelayanan K-14

\begin{tabular}{|c|c|c|c|c|c|c|}
\hline \multirow{3}{*}{ No. } & \multirow{3}{*}{$\begin{array}{l}\text { Lokasi Tempat Perhentian } \\
\text { Angkutan Umum }\end{array}$} & \multicolumn{4}{|c|}{ Kriteria Pemilihan Tipe TPAB } & \multirow{3}{*}{ Rekomendasi Tipe Tempat Perhentian Angkutan Umum (TPAB) } \\
\hline & & $\begin{array}{c}\text { Apakah mungkin dibuat } \\
\text { teluk bus? }\end{array}$ & \begin{tabular}{|c|} 
Apakah perlu \\
lindungan (halte)?
\end{tabular} & $\begin{array}{l}\text { Apakah Ada } \\
\text { trotoar? }\end{array}$ & $\begin{array}{c}\text { Apakah jalur lalu lintas } \\
\text { per arah }>5,75 \mathrm{~m} ?\end{array}$ & \\
\hline & & 1 & 2 & 3 & 4 & \\
\hline 1 & Kampung Utan (Terminal) & $\sqrt{ }$ & - & $\sqrt{ }$ & - & TPB yang terpadu dengan fasilitas pejalan kaki dan dilengkapi dengan teluk bus; \\
\hline 2 & Simpang 3 Sate Solo & $\sqrt{ }$ & $\sqrt{ }$ & - & - & Halte yang tidak terpadu dengan trotoar dan dilengkapi dengan teluk bus; \\
\hline 3 & SDN Cibuntu 01 & $\sqrt{ }$ & $\sqrt{ }$ & - & - & Halte yang tidak terpadu dengan trotoar dan dilengkapi dengan teluk bus; \\
\hline 4 & Gazebo & $\sqrt{ }$ & $\sqrt{ }$ & - & - & Halte yang tidak terpadu dengan trotoar dan dilengkapi dengan teluk bus; \\
\hline 5 & Gang Onte & - & $\sqrt{ }$ & - & - & TPB yang tidak terpadu dengan trotoar dan dilengkapi dengan teluk bus; \\
\hline 6 & SDN Cibuntu 06 & $\sqrt{ }$ & $\sqrt{ }$ & - & - & Halte yang tidak terpadu dengan trotoar dan dilengkapi dengan teluk bus; \\
\hline 7 & ATM BNI STTD & $\sqrt{ }$ & $\sqrt{ }$ & - & - & Halte yang tidak terpadu dengan trotoar dan dilengkapi dengan teluk bus; \\
\hline 8 & STTD & $\sqrt{ }$ & $\sqrt{ }$ & - & - & Halte yang tidak terpadu dengan trotoar dan dilengkapi dengan teluk bus; \\
\hline 9 & BPLJSKB & $\sqrt{ }$ & $\sqrt{ }$ & - & - & Halte yang tidak terpadu dengan trotoar dan dilengkapi dengan teluk bus; \\
\hline 10 & Perumahan Hubdat & $\sqrt{ }$ & $\sqrt{ }$ & - & - & Halte yang tidak terpadu dengan trotoar dan dilengkapi dengan teluk bus; \\
\hline 11 & Simpang 3 Rawa Banteng & - & - & - & - & Pada lahan terbatas yang tidak memungkinkan membuat teluk bus, hanya disediakan \\
\hline 12 & Industri Batik & $\sqrt{ }$ & $\sqrt{ }$ & - & - & Halte yang tidak terpadu dengan trotoar dan dilengkapi dengan teluk bus; \\
\hline 13 & Komplek Gedung Pertanian & $\sqrt{ }$ & $\sqrt{ }$ & - & - & Halte yang tidak terpadu dengan trotoar dan dilengkapi dengan teluk bus; \\
\hline 14 & Perum Grand Mutiara Gading & $\sqrt{ }$ & $\sqrt{ }$ & - & - & Halte yang tidak terpadu dengan trotoar dan dilengkapi dengan teluk bus; \\
\hline 15 & Perum Graha Asri & $\sqrt{ }$ & $\sqrt{ }$ & - & - & Halte yang tidak terpadu dengan trotoar dan dilengkapi dengan teluk bus; \\
\hline 16 & SD Telajung 01 & $\sqrt{ }$ & $\sqrt{ }$ & - & - & Halte yang tidak terpadu dengan trotoar dan dilengkapi dengan teluk bus; \\
\hline 17 & Pertigaan Setu (Terminal) & - & - & - & - & Pada lahan terbatas yang tidak memungkinkan membuat teluk bus, hanya disediakan \\
\hline \multicolumn{7}{|c|}{ Keterangan: } \\
\hline$\sqrt{ }$ & :Ya & & & & & \\
\hline- & : Tidak & & & & & \\
\hline
\end{tabular}




\section{H. KESIMPULAN}

Berdasarkan hasil pembahasan yang telah dilakukan pada bagian sebelumnya, berikut disampaikan beberapa hasil penelitian berkaitan dengan penentuan lokasi tempat perhentian angkutan umum (TPAU) pada pelayanan Trayek K-14 di Kabupaten bekasi:

4. Rute pelayanan Trayek K-14 adalah Jalan Raya Setu, yang terbentang dari Kampung UtanSimpang Tiga Setu. Jumlah armada yang beroperasi sebanyak 224 kendaraan, sedangkan jumlah kendaraan yang diijinkan hanya 110 kendaraan. Jadi tingkat operasi armada pada Trayek K-14 adalah 203,6\%.

5. Waktu tempuh rata-rata untuk trayek K.14 adalah 39,5 menit dengan kecepatan rata-rata 27,28 km/jam. Jumlah Penumpang.km rata-rata adalah 11,8 pnp.km. Frekuensi kendaraan sebesar 45 kendaraan/ jam dan waktu antara kendaraan (headway) rata-rata adalah 1,32 menit dan load faktor rata-rata adalah 36.80\%. Load factor yang kecil ini diakibatkan jumlah kendaraan yang beroperasi sangat banyak (tingkat operasi 203\%) dan kurangnya tingkat pemerataan penumpang pada jam sibuk dengan jam tidak sibuk.

6. Terdapat kurang lebih 24 (dua puluh empat) titik potensial sebagai lokasi TPAU berdasarkan lokasi kantung-kantung penumpang.

7. Dengan menerapkan metode pemilihan lokasi yang mempertimbangkan kriteria tata guna lahan, lokasi sedekat mungkin dengan perumahan dan kantung-kantung penumpang, jarak antar lokasi anternatir TPAU serta lokasi TPAU di titik persimpangan, maka terpilihlah 17 (tujuh belas) lokasi TPAU yang layak untuk dibangun menurut lokasi yang ideal.

8. Dengan memperhatikan tata guna lahan, ketersediaan trotoar, perlu atau tidak atas perlindungan, dan lebar jalur lalu lintas per arah, diperoleh jenis perhentian angkutan umum yang tepat untuk dibangun yaitu:

- Tempat pemberhentian bus (TPB) yang terpadu dengan fasilitas pejalan kaki dan dilengkapi dengan teluk bus;

- Halte (atap perlindungan) yang tidak terpadu dengan trotoar dan dilengkapi dengan teluk bus;

- Tempat pemberhentian bus (TPB) yang tidak terpadu dengan trotoar dan dilengkapi dengan teluk bus;

- Pada lahan terbatas yang tidak memungkinkan membuat teluk bus, hanya disediakan Tempat pemberhentian bus (TPB) dan rambu larangan menyalip. 


\section{SARAN}

Memperhatikan proses analisis hingga hasil analisis penentuan lokasi halte pada pelayanan angkutan umum Trayek K-14 pada bagian sebelumnya dapat diberikan saran untuk penelitian lebih lanjut sebagai berikut:

1. Dalam proses analisis, diperlukan data tata guna lahan yang memadai, namun dari hasil pengumpulan data sekunder pada instansi terkait, peta RBI yang diperoleh tidak memberikan informasi yang cukup mengenai tata guna lahan, sehingga sebagian analisis yang seharusnya dapat dilakukan dalam perangkat aplikasi Sistem Informasi Geografis tidak dapat dilakukan. Oleh karenanya, data tata guna lahan harus sudah dipastikan diperoleh sebelum proses analisis lanjutan. Namun demikian analisis dilakukan dengan cara manual.

2. Proses analisis belum bisa sepenuhnya dilakukan dalam perangkat aplikasi GIS, oleh karenanya pada penelitian berikutnya perlu eksplorasi pemanfaatan fitur aplikasi GIS sedemikian hingga sehingga pemanfaatan teknologi GIS dapat dilakukan secara maksimal sehingga analisis dapat dilakukan secara lebih optimal.

3. Penetapan kriteria pemilihan perlu ditambahkan, misalnya berkaitan dengan kondisi daya dukung tanah, daerah bukit atau pegunungan, daerah patahan dan lain-lain.

4. Pemberian skor pada setiap nilai suatu kriteria pemilihan perlu ditetapkan dengan memperhatikan pertimbangan pengambil kebijaka, seperti calon penumpang, pengemudi dan pemerintah sebagai pengelola jasa angkutan serta masyarakat sebagai objek penderita secara tidak langsung akibat dari penetapan lokasi TPAU. 